13.00.00 Pedagogic sciences

13.0о.оо Педагогические науки

UDC 372

\title{
Russia and Ukraine: Media Literacy Education Approaches
}

\author{
Alexander V. Fedorov
}

Anton Chekhov Taganrog State Pedagogical Institute, Russia

Iniciativnaya street 48, Taganrog city, Rostovskaya oblast, 347936

Dr. (Education), Professor

E-mail: 1954alex@mail.ru

\begin{abstract}
For many decades of the Soviet period the development of media education in Russia and Ukraine has been practically coinciding. Media educational lessons (mainly on the material of cinematography and the press) were of optional and focal character and depended on the enthusiasm of certain teachers. In theory and methodology the aesthetic and practical approaches predominated. In the 1960es - 1980es the most active was the Kiev group of Ukrainian film educators. Besides study groups, elective courses (aesthetic approach) and film/photo/video studious, school and university amateur newspapers and magazines (practical approach) media education was developing in an integrating form - within the compulsory subjects as literature, history, Russian, Ukrainian and foreign languages. The situation changed in modern times: Russia is leading in media education literacy researches, and Ukraine - in the practical media education in schools.
\end{abstract}

Keywords: Russia, Ukraine, media education literacy, schools, students.

INTRODUCTION. For many decades of the Soviet period the development of media education in Russia and Ukraine has been practically coinciding (see: Silina, 1968; Fedorov, 2001; Fedorov, Chelysheva, 2002; Chashko, 1979, etc.). Media educational lessons (mainly on the material of cinematography and the press) were of optional and focal character and depended on the enthusiasm of certain teachers. In theory and methodology the aesthetic and practical approaches predominated (see: Silina, 1968; Fedorov, Chelysheva, 2002; Chashko, 1979, etc.). In the 1960es - 1980es the most active was the Kiev group of Ukrainian film educators (O. Musienko, V. Silina, L. Chashko, etc.). Besides study groups, elective courses (aesthetic approach) and film/photo/video studious, school and university amateur newspapers and magazines (practical approach) media education was developing in an integrating form - within the compulsory subjects as literature, history, Russian, Ukrainian and foreign languages.

MATERIALS AND METHODS. Russia. In the early 1990es thanks to the works of A.V. Sharikhov (Sharikhov, 1990; 1991) the ideas of the leading western media educators began to spread in Russia. A number of international conferences organized by Russian Association for Film and Media Education and the company VIKING led by G.A. Polichko supported acquaintance with the western concepts of media education.

The laboratory of screen arts of the Institute of Art Education of Russian Academy of Education headed by Y.N. Usov continued to develop and improve the aesthetic concept of media education. However in the second half of the 1990es the programs of integrated media education for schools based on practical approaches and the theory of the development of critical thinking have been developed in the laboratory of technical training aids and media education of Russian Academy of Education under the direction of L.S. Zaznobina. The experience of the laboratory of media educational sociology in Samara also proved to be interesting (chief scientist - Professor of Higher School of Economics A.V. Sharikhov).

In the late 1990es - the beginning of the 21st century a group of media educators of Taganrog State Pedagogical Institute has developed a set of documents for introduction of a new university media education specialization. In 2002 Russian Ministry of Education and Science officially approved and registered the new specialization for pedagogical institutes of higher education numbered 03.13.30. 
"Media Education" which now can be taught at any Russian university or pedagogical institute. In September, 2002 Taganrog State Pedagogical University began to train teachers in this specialization.

In the 2000es the number of publications on media education in Russia dramatically increased. From 2001 till 2008 more than 60 monographs and textbooks, dozens of scientific journals and hundreds of articles on media education, media literacy and media competence were published. With the support of ICOS UNESCO “Information for All” and the UNESCO Office in Moscow a specialized magazine "Media Education" is regularly issued nationwide since 2005. In the 2000es a number of Russian websites dedicated to media education were created.

From 1992 till 2012 Russian media educators have received grants (including the Federal target program) of the Ministry of Education and Science of the Russian Federation, Russian Humanitarian Scientific Foundation, the Russian Foundation, Russian Foundation for Fundamental Research, President's Program "Support for Leading Scientific School of Russia”, UNESCO, the number of foreign foundations ("Open Society Institute", MION - Ino-center, Fulbright, IREX, DAAD, etc.). More than 40 research grants were received in the last 10 years. Thanks to these grants Russian scientists were able to work in the leading research centers in Washington, New York, Paris, Brussels, Berlin Budapest, Toronto and other cities all over the world; to participate in major international scientific conferences on media education (in the USA, Canada, France, Great Britain, Germany, Austria, Switzerland, Spain, Brazil, Poland, Czech Republic, etc.). So it's not surprising that more than 40 theses on media education, media competence and media literacy have been successfully defended from 2000 till 2010.

In 2008 Taganrog State Pedagogical Institute and Russian Association for Film and Media Education became the official partners of the United Nations in the new project: an agreement with the management of "United Nations' Alliance of civilizations" was signed to create the Russian segment of an international website Media Literacy Education (http:.www.aocmedialiteracy.org).

Nearly at the same time was created of a nationwide website "Information Literacy and Media Education" (http:.www.mediagram.ru). The web is already filled with full-text materials - monographs, textbooks and programs, abstracts and articles on media education and information literacy. All of them are publicly available and can be used in the educational process as well as in the process of selfeducation of a wider audience.

Recently the Public Chamber at the State Duma of the Russian Federation has become interested in problems of the development of media education and the improvement of information literacy of the Russians as well. Anyway these questions were frequently discussed at its working sessions. In 20062012 new organizations supporting and developing media education appeared in Russia: Siberian Association for Media Education, Ural Research and Methodical Center for Media Culture and Media Education (http:.www.urfomediacenter.ru), Regional Center for Media, which became the initiator of the publication of a new Russian magazine - "Education. Media. Society: the Space for Cooperation", which has been issued since 2007.

The scientific school of Doctor of philological sciences, dean of the Faculty of J ournalism of Belgorod State University, Prof. A.P. Korochensky, who investigates educational processes at the junction of media criticism and media education (Korochensky, 2003), is gaining momentum.

Moreover, all these new organizations and associations have already succeeded in conducting international and Russian conferences on media education.

We can name the particular Russian educators actively promoting the ideas of media education in theory and practice. Besides Taganrog State Pedagogical Institute (A.V. Fedorov, I.V. Chelysheva, E.V. Muryukina, N.P. Ryzhikh, V.L. Kolesnichenko and others), training courses on media education and media culture are lectured nowadays in the State University of Management (G.A. Polichko), Moscow Institute of Open Education (M.A. Fominova), Yekaterinburg State University (N.B. Kirillova), Sholokhov Moscow university (I.V. Zhilavskaya), Chelyabinsk State Unversity (I.A. Fateeva), The Southern Ural State University in Chelyabinsk (A.V. Minbaleev), Tambov State University (V.A. Monastyrskiy), Biysk State Pedagogical University (V.A. Vozchikov), Irkutsk State Pedagogical Institute of Foreign Languages (L.A. Ivanova), Kurgan State University (N.A. Legotina), Omsk State University (N.F. Khilko), The Southern Federal University (L.V. Usenko), Rostov State Economical University (G.P. Maksimova), Altai State Academy of Culture and Arts (O.P. Kutkina), Pomorski State University (O.V. Pechinkina), Krasnodar University of Culture and Arts (T.F. Shak).

The heads of the laboratories of Screen Arts and Media Education and experimentation of Russian Academy of Education L.M. Bazhenova, E.V. Bondarenko, S.I. Gudilina teach at different Moscow educational institutions. One of the founders of Russian media education professor of Tver 
State University O.A. Baranov continues his fruitful activity in media education. Schoolchildren implement interesting network media education projects with the help of textbooks and under the guidance of E.N. Yastrebtsova, E.V. Yakushina and O.Y. Latysheva (Russian Academy of Education). Similar internet projects for schoolchildren are created by teachers of the Center for Media Education in Togliatti.

We can mention the names of the most prominent teachers in Russian high schools who introduce media education in the educational process: E.I. Golubeva (Moscow High School №1161), T.P. Kadubets, L.A. Karepova (Sayansk High School № 6), T.V. Kovsharova (Irkutsk Gymnasium №3), Y.S. Skvortsova (Voskresensk High School №9), N.G. Hitsova (Irkutsk Regional Art School for Children), A.I. Voronin (St. Petersburg High School №156), I.A. Serikova (Lyceum "Erudit”, Rubtsovsk, Altai Territory) and many others. Most of the above mentioned colleagues are members of the Russian Association for Film and Media Education.

In February 2008 at Moscow State University a resolution was adopted at the round table on media education. This resolution highlighted the achievements of the scientific school "Media Education and Media Competence" at Taganrog State Pedagogical Institute. It was also mentioned that "the richest experience in media education has been accommodated in Moscow, Voronezh, Tver, St. Petersburg, Yekaterinburg, Kurgan, Rostov, Taganrog, Tambov, Krasnodar, Chelyabinsk. The Association for Film and Media Education and Siberian Association for Media Education conduct an active work on popularization of the ideas of media education" (http:.www.edu. of.ru /mediaeducation/news.asp?ob no=32087).

Ukraine. "Ukrainian Pedagogical Dictionary" which was published in Kiev in 1990-s (Goncharenko, 1997) gave practically the same definition of the term "media education" as it was defined in "Russian Pedagogical Encyclopedia": a direction in pedagogics that speaks for the study of the "regularities of mass communication" (the press, television, radio, cinema, video, etc.) by schoolchildren and students. The main tasks of media education: to prepare the next generation for the life in modern information world, for the perception of different information; to teach a person to understand it, realize the consequences of its influence on the psyche, to master the means of communication on the basis of non-verbal forms of communication with the help of technical aids" (Media Education, 1993, p.555). In general the first half of the 1990-es wasn't productive for Ukrainian media educators: apparently the political and economical problems made it impossible to concentrate on the "secondary" directions in pedagogics. Although some individual notable actions (conferences, festivals) were conducted, for example, by the National Association for Film Education of Ukraine under the leadership of its president - O.S. Musiyenko...

A new page in Ukrainian media education movement began in 1999 when the Institute of Ecology of Mass Information under the leadership of B. Potyatinnik was created in Lviv National University. B. Potyatinnik established cooperation with the U.S. media education associations and headed for the development of new approaches in the field of media pedagogics. For example, in September 2002 the leaders of the Institute of Ecology of Mass Information B. Potyatinnik and N. Gabor successfully organized and conducted an international scientific and practical conference "Media Education as a Part of Citizen's Education" (Media Attack, 2002). These media educators created and introduced into the educational process of Lviv school № 77 an elective course "Media Education in the Ukraine" for 7-11 grades (http:.www.mediaeducation.iatp.org.ua/ page2.html).

According to its name, the Institute of Ecology of Mass Information to some extent staked on the development of "protective", "precautionary" approaches based on the negative influence of media (Gabor, 2002, pp.49-52; Media Attack, 2002, pp.61-90). The leader of the Lviv school of media education B.V. Potyannik is sure that "media education is a scientific and educational sphere of activity which aims to help the individual in developing psychological defense against manipulation or exploitation by mass media and to develop/inculcateinformational culture" (Potyatinnik, 2005, p.8).

However the materials of the web of the institute and numerous roundtables and conferences (Media Attack, 2002), held under its aegis, show that such conœepts as semiotic, cultural, social and cultural, theory of the development of critical thinking are also considered the basic ones. According to the Lviv approach "the Ukrainian version" of media education is based not only on the joint efforts of educators, but psychologists, journalists, lawyers and priests as well (Gabor, 2002, p.50). The most complete view of the Lviv school of media ecology, media criticism and media education is represented in the monograph "Media: the Keys to Understanding" by B.V. Potyatinnik (Potyatinnik, 2004). 
In particular, considerable attention is paid not only to the theories of media, but also the problems of media violence, the consequences of its influence on the underage audience.

In the beginning of the $21^{\text {st }}$ century a Kiev group of media education brightly showed itself thanks to the efforts of Doctor of Pedagogical Science, Professor G.V. Onkovich (Institute of Higher Education of the Academy of Pedagogical Sciences of Ukraine). In his works G.V. Onkovich points out rightly that the audience of media education should not be limited to students only: adults also need to be media literate (Onkovich, 2007). Moreover G.V. Onkovich reasonably draws attention to the necessity of self media education (Onkovich, 2007(a), c.29-31). At the forefront of his theoretical concept G.V. Onkovich puts the ideas of media didactics (Onkovich, 2007). In personal scientific discussions with G.V. Onkovich I managed to learn that in her understanding media didactics has subsections corresponding to different types of media: the press, radio, cinema, television, etc.

DISCUSSIONS. Russian situation. However further in the resolution the negative tendencies in the development of Russian media education process are rightly marked: "the accommodated experience and research results remain rather unknown and are not used in full force due to the fact that media education has still not moved from the experimental stage to the stage of wide practical application. It should be also recognized that the role of faculties of journalism and the media community as a whole in media education is insufficient. The potential for additional education at the faculties of journalism is poorly used. The cooperation with the existing centers and numerous experimental sites in the field of media education is insufficient as well; the potential of teachers and researchers of the leading faculties is not fully used".

The conclusion of the resolution states that the task of the formation of media competent audience which is prepared to live and work in the information society is extremely important and urgent for the development of media education. Therefore it is necessary to "develop the concept of media education courses for students of faculties and departments of journalism, courses for the improvement of professional skills for practicing journalists and teachers of additional education in the field of media education; to propose the Ministry of Education and Science of the Russian Federation to consider the relevance and expediency of introduction of media education component into the program of secondary education".

In my opinion the main difficulties in wider introduction of media education into the educational process of Russian institutions of higher education and schools are primarily related to:

- the obvious lack of specifically trained media educators;

- a certain inactivity of the leadership of some pedagogical institutes of higher education (as is known wide opportunities for introduction of new disciplines of various subjects are provided to the universities within the framework of the regional component and elective courses, but their Academic Boards are still giving very few hours for media education subjects which are so necessary for the future teachers);

- with the traditional approaches of the structures of the Ministry of Education and Science, which are concentrating their attention on the support of training courses in information science and information technologies of education at considerably less attention to the urgent problems of media education.

Naturally I don't mean the Russian universities and faculties which prepare professional practitioners in the field of media (journalists, film directors, producers, advertising managers, etc.), where a wide range of subjects related to media is lectured. Here (just like in the Ukrainian specialized universities and faculties) the situation completely meets the European standards. I am much more concerned about media education on the future teachers who will work in schools after graduation. And of course about media education of schoolchildren who spend a significant part of their lives in the virtual world, the world of media.

Ukrainian situation. Head of the Laboratory of Psychology of Mass Communication and Media Education of the Institute of Social and Political Psychology of the Academy of Pedagogical Sciences of Ukraine L.A. Naidyonova has developed a model of media culture which consists of four interconnected units: "reactions" (search for information, its reading/scanning, identification/ recognition of media texts), "actualization" (assimilation, integration of new knowledge related to the media), "generation" (incubation, creative conversion, transformation of media knowledge and skills), "use" (transmission of information, innovation activity, research in the field of media) (Naidyonova, 2007, pp.165-166). 
To some extent this model corresponds to our model of the development of media competence and critical thinking of students of pedagogical institutes in classes of media education cycle (Fedorov, 2007, p.145), in which we distinguished theoretical (the unit of teaching the audience the theory of media, the unit of the development of media education motivation and technology) and practical (the unit of creative activity, the unit of perceptive and analytical activity) components. However in our model diagnostic and resulting components are singled out separately, while in L.A. Naidyonova's model they seem to be built in each of the four units that she distinguished. These are such indicators as differentiated selection, the ability to evaluate media texts, "energy charge" for "search", "actualization", "generation" and "use" of media and media texts (Naidyonova, 2007, p. 167).

Following the ideas of the British scientist L. Masterman, Ukrainian scientists has recently begun to closely associate media education and the development of critical thinking (Tyaglo, 2002, p.35). At the same time they admit the importance of the autonomous professional and mass media education, though paying more attention to the analysis of the possibilities of integrated media education, for example on the linguistic material (Onkovich, 1997, pp.19-24; Yanishin, 2007, pp.430431), in the preparation of PR-specialists (Nedokhodyuk, 2007, pp.194-197), etc.

In his thesis A.D. Onkovich proves the effectiveness of media education on the material of the press and other mass media on the basis of the following cycle of creative assignments:

- study of information about the educational press (taking into consideration the peculiarities of the development of the education system in the given country);

- study of the "assembly" language of an issue (or TV/ radio programs);

- commenting rubrics, reviewing related articles, broadcasts;

- general analysis of the materials of periodicals (the press, TV/ radio programs);

- the analysis of the genre palette of modern journalism, actualization of the "genre image";

- work on the problem article on theimportant topic;

- the analysis of the problems of the issue, the characteristics of its publishers and authors;

- work with the specific vocabulary of the issue (terminology, common syntax, etc.);

- the analysis of the presentation of celebrities the issue wrote about;

- commenting urgent problems, reflected in the issue (Onkovich, 2004, p.16).

At the same time the contemporary Ukrainian media educators is devoid of national insularity, they carefully analyze Russian (Barishpolets, 2008; Bondur, 2005; Buzhikov, 2007; Onkovich, 2007; Chemeris, 2006), German (Rumyantsev, 2002, pp.10-17; Robak, 2006, pp.275- 286), French (Onkovich, 2007), American (Gabor, 2002, pp.50-51; Onkovich, 2007), British and Canadian (Gabor, 2002, p.49; Onkovich, 2007; Chernyavska, 2005; 2006) media education experience. In particular, the first translations of Russian articles into the Ukrainian language appeared (Fedorov, 2008).

Unfortunately the researches of the Ukrainian media educators hardly receive any financial support from the Ministry of Education of Ukraine and Ukrainian state research foundations. Foreign foundations don't support them too much as well. The most vivid example was Media Literacy Program in the CIS (2006-2009) supported by grant ReSET-HESP (http:.wwwnew.towson. edu/medialiteracy/localaboutus.htm). Boris Potyatinnik's project "Electronic Magazine of the Institute of Media Ecology "Media Education" http:www.franko.lviv.ua/mediaeco/zurnal/indexukr.htm, initiated in 2001 with the support of the International Foundation "Renaissance".

The list of theses defended by Ukrainian educators from 1992 to 2012, as well as monographs, textbooks on media education isn't very impressive too.

The situation changed in modern times: Russia is leading in media education literacy researches, and Ukraine - in the practical media education in schools (the experiment of Ukrainian Ministry of Education 2011-2012).

Study and the analysis of media education in Russia and Ukraine allowed me to make a comparative analysis of media education approaches in the two countries. The results are summarized in Table1. 


\begin{tabular}{|c|c|c|c|}
\hline $\mathbf{N}$ & $\begin{array}{l}\text { Media } \\
\text { education } \\
\text { situation }\end{array}$ & Ukraine & Russia \\
\hline 1 & $\begin{array}{l}\text { Leading } \\
\text { media } \\
\text { educational } \\
\text { organizatio } \\
\text { ns and } \\
\text { periodicals }\end{array}$ & $\begin{array}{l}\text { The institute of macro ecology at } \\
\text { Lviv National University } \\
\text { http:.www.franko.lviv.ua/mediaeco } \\
\text { Lindex.htm } \\
\text { The Laboratory of Psychology of } \\
\text { Mass Communication and Media } \\
\text { Education of the Institute of Social } \\
\text { and Political Psychology of the } \\
\text { Ukrainian Academy of Pedagogical } \\
\text { Sciences. } \\
\text { Institute of Higher Education of the } \\
\text { Ukrainian Academy of Pedagogical } \\
\text { Sciences. } \\
\text { Ukrainian National Association for } \\
\text { Film Education. } \\
\text { Research and practical team from } \\
\text { Kiev National University (head is } \\
\text { Prof. Dr. V.Ivanov) for practical } \\
\text { development media education in } \\
\text { Ukraine. }\end{array}$ & $\begin{array}{l}\text { Russian Association for Film and Media } \\
\text { Education } \\
\text { http:.edu.of.ru/mediaeducation } \\
\text { http..www.medialiteracy.boom.ru } \\
\text { http:.www.mediaeducation.boom.ru } \\
\text { Russian Federation of Internet Education } \\
\text { http:.www.fio.ru } \\
\text { YNPRESS http:.www.ynpress.com } \\
\text { Media School YNPRESS: } \\
\text { http:.www.mediashkola.ru } \\
\text { The Laboratory of Screen Arts of the } \\
\text { Institute of Arts Education of the Russian } \\
\text { Academy of Education } \\
\text { http:.www.art-education.ru/ otd-dop- } \\
\text { ekran.htm } \\
\text { The Laboratory of Technical Aids and Media } \\
\text { Education of the Institute of General } \\
\text { Secondary Education of the Russian } \\
\text { Academy of Education } \\
\text { http:.www.mediaeducation.ru } \\
\text { The Research Laboratory "School Media } \\
\text { Library" of the Russian Academy of } \\
\text { Education: } \\
\text { http:.www.ioso.ru/scmedia } \\
\text { The Department of Social and Cultural } \\
\text { Development of the Taganrog State } \\
\text { Pedagogical Institutehttp:.www.tgpi.ru } \\
\text { Regional Center for Media Education } \\
\text { (Yekaterinburg) } \\
\text { http:.www.omo-ps.ru/ } \\
\text { Ural Scientific and Methodical Center for } \\
\text { Media Culture and Media Education: } \\
\text { http:.www.urfomediacenter.ru } \\
\text { The development of critical thinking through } \\
\text { reading and writing (RKMCHP) and media } \\
\text { education: } \\
\text { http:.ct-net.net/ru/ct_proj_med ru }\end{array}$ \\
\hline 2 & $\begin{array}{l}\text { Periodicals } \\
\text { and full-text } \\
\text { digital } \\
\text { libraries on } \\
\text { media } \\
\text { education, } \\
\text { publishing } \\
\text { of } \\
\text { monograph }\end{array}$ & $\begin{array}{l}\begin{array}{l}\text { Internet journal “Media } \\
\text { Education" } \\
\text { http:.www.franko.lviv.ua/mediaeco }\end{array} \\
\text { Izurnal/indexukr.htm } \\
\text { Media Education: Ukraine: } \\
\text { http:.www.edu.of.ru/mediaeducati } \\
\text { on/default.asp?ob no=30060 }\end{array}$ & $\begin{array}{l}\text { J ournal “Media Education” (printed } \\
\text { and digital versions) } \\
\text { http:.www.mediagram.ru/mediaed/journal/ } \\
\text { http:.www.ifap.ru/projects/mediamag.htm } \\
\text { http:.www.edu.of.ru/mediaeducation/defaul } \\
\text { t.asp?ob no=6096 } \\
\text { http:.www.edu.of.ru/medialibrary/ default.as } \\
\text { p?ob no=34437 } \\
\text { J ournal "Education. Media. Society: }\end{array}$ \\
\hline
\end{tabular}




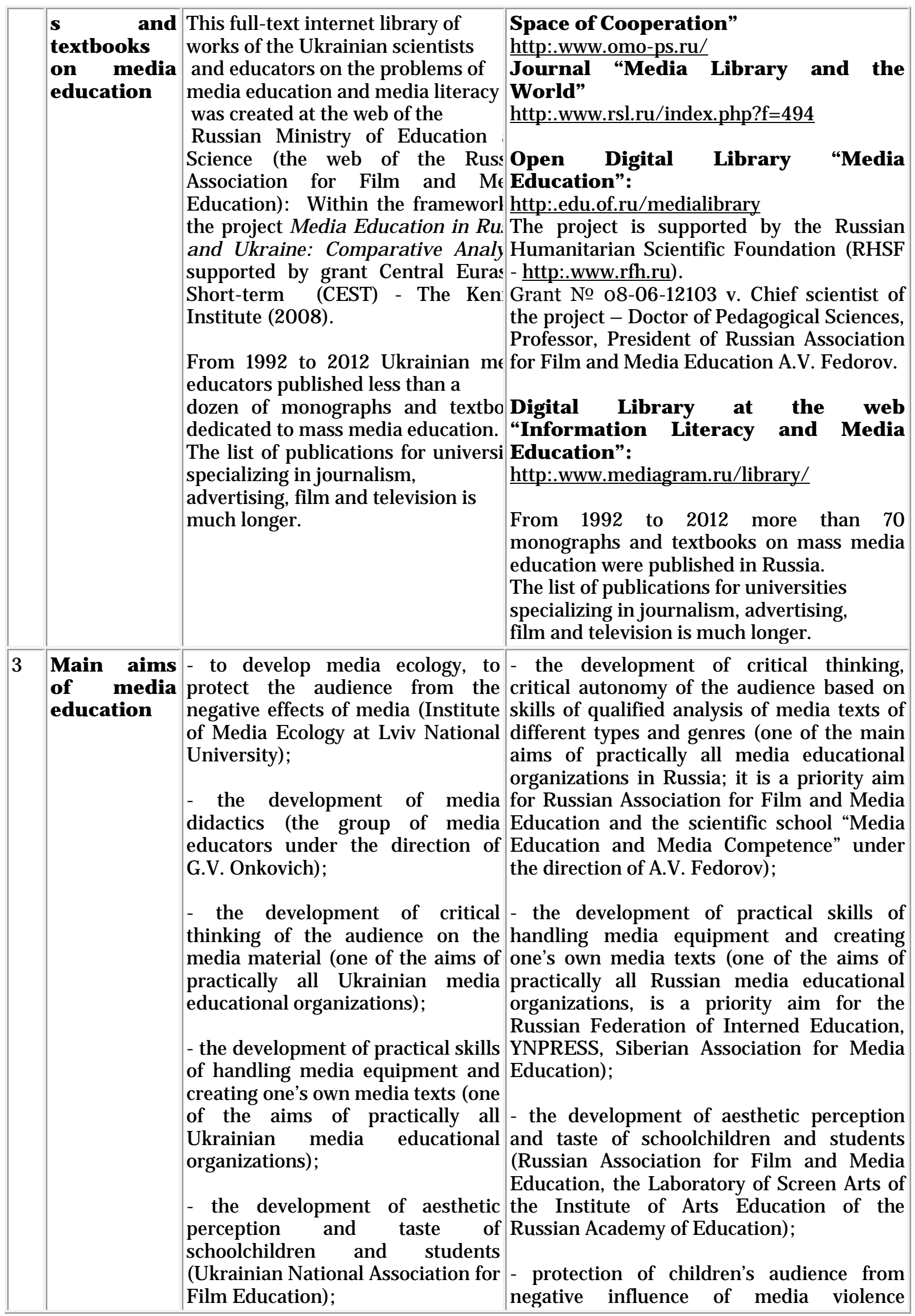




\begin{tabular}{|c|c|c|c|}
\hline & & & $\begin{array}{l}\text { (Russian Association for Film and Media } \\
\text { Education); }\end{array}$ \\
\hline 4 & $\begin{array}{l}\text { Main } \\
\text { theories of } \\
\text { media } \\
\text { education }\end{array}$ & $\begin{array}{l}\text { - protective theory; } \\
\text { - theory of media ecology; } \\
\text { - "practical" theory; } \\
\text { - theory of the development of } \\
\text { critical thinking; } \\
\text { - social and cultural theory; } \\
\text { - aesthetic theory; }\end{array}$ & $\begin{array}{l}\text { - aesthetic theory; } \\
\text { - theory of the development of critical } \\
\text { thinking and critical autonomy; } \\
\text { - culture studies theory of personality } \\
\text { development; } \\
\text { - "practical" theory; } \\
\text { - social and cultural theory; }\end{array}$ \\
\hline 5 & $\begin{array}{l}\text { Basic media } \\
\text { educational } \\
\text { models }\end{array}$ & $\begin{array}{l}\text { - "protective", media ecological } \\
\text { model that includes the } \\
\text { development of critical thinking at } \\
\text { all levels of education; } \\
\text { - media didactic model (orientation } \\
\text { toward a number of didactic } \\
\text { models related to film education, } \\
\text { education on the material of the } \\
\text { press, television, radio, Internet, } \\
\text { etc.) at all levels of education; } \\
\text { - the model of media culture (which } \\
\text { consists of four interconnected } \\
\text { units: "reactions" (search for } \\
\text { information, its reading/scanning, } \\
\text { identification/recognition of media } \\
\text { texts), "actualization" (assimilation, } \\
\text { integration of new knowledge } \\
\text { related to the media), "generation" } \\
\text { (incubation, creative conversion, } \\
\text { transformation of media knowledge } \\
\text { and skills), "use" (transmission of } \\
\text { information, innovation activity, } \\
\text { research in the field of media) - at } \\
\text { all levels of education; } \\
\text { - practical (the study of the use of } \\
\text { media in practice) - at all levels of } \\
\text { education including schools, } \\
\text { institutes of higher education and } \\
\text { institutions of further education; } \\
\text { social and cultural development of } \\
\text { personality; } \\
\text { - social and cultural development of } \\
\text { personality (the development of } \\
\text { aesthetic perception and taste, } \\
\text { interpretation analysis, etc.) - at all } \\
\text { levels of education; }\end{array}$ & $\begin{array}{l}\text { - the development of critical thinking, } \\
\text { creative abilities on media material at all } \\
\text { levels of education. } \\
\text { - educational and aesthetic models (the } \\
\text { study of moral, philosophical problems on } \\
\text { media material), mainly in high school and } \\
\text { in the institutes of higher education; } \\
\text { - practical (the study of the use of media in } \\
\text { practice) - at all levels of education } \\
\text { including schools, institutes of higher } \\
\text { education and institutions of further } \\
\text { education; } \\
\text { social and cultural development of } \\
\text { personality (the development of perception } \\
\text { and taste, critical thinking, interpretation, } \\
\text { analysis of media texts, etc.) - at all levels of } \\
\text { education. } \\
\text { Here we can distinguish theoretical (the unit } \\
\text { of teaching the audience the theory of media, } \\
\text { the unit of the development of media } \\
\text { education motivation and technology) and } \\
\text { practical (the unit of creative activity, the } \\
\text { unit of perceptive and analytical activity) } \\
\text { components (A.V. Fedorov). Plus diagnostic } \\
\text { and resulting components of the model, with } \\
\text { the corresponding indicators of media } \\
\text { competence (motivational, contact, } \\
\text { informational, perceptive, } \\
\text { interpretational/ evaluative, practical and } \\
\text { operational/activity-related and creative); } \\
\text { - educational and informational (the study of } \\
\text { theory and history of media culture and } \\
\text { language of media), mainly at the high } \\
\text { school level; }\end{array}$ \\
\hline
\end{tabular}




\begin{tabular}{|c|c|c|c|}
\hline & & $\begin{array}{l}\text { - educational and informational } \\
\text { (the study of theory and history of } \\
\text { media culture and language of } \\
\text { media), mainly at the high school } \\
\text { level; }\end{array}$ & \\
\hline 6 & $\begin{array}{l}\text { Key topic of } \\
\text { media } \\
\text { education } \\
\text { lessons }\end{array}$ & $\begin{array}{l}\text { Media ecology, media didactics, } \\
\text { media language, media audience, } \\
\text { mediar categories, redia } \\
\text { technologies, media agencies, } \\
\text { media representations, theory and } \\
\text { history of media culture, problems } \\
\text { of media violence, etc. }\end{array}$ & $\begin{array}{l}\text { Media perception, audiovisual perception, } \\
\text { media language, media audience, media } \\
\text { categories, media technologies, media } \\
\text { agencies, media representations, theory and } \\
\text { history of media culture, problems of media } \\
\text { violence, etc. }\end{array}$ \\
\hline 7 & $\begin{array}{l}\text { Grant } \\
\text { support of } \\
\text { scientific } \\
\text { research in } \\
\text { the field of } \\
\text { media } \\
\text { education }\end{array}$ & $\begin{array}{l}\text { We have no information about } \\
\text { grant support of media educational } \\
\text { projects from ministries or } \\
\text { Ukrainian state scientific } \\
\text { foundations. } \\
\text { Support of media education by } \\
\text { foreign foundations is fragmentary. } \\
\text { The number of theses on media } \\
\text { educational subjects defended by } \\
\text { Ukrainian educators in } 21^{\text {st }} \text { century } \\
\text { is less than a dozen. }\end{array}$ & $\begin{array}{l}\text { Grants of the Russian Ministry of Education } \\
\text { and Science (1999-2012), Russian } \\
\text { Humanitarian Scientific Foundation, the } \\
\text { Russian Foundation (1997-2012), Russian } \\
\text { Foundation for Fundamental Research } \\
\text { (2002-2004), } \\
\text { Presidential Program "Support of Russia's } \\
\text { Leading Scientific Schools "(2003-2005), } \\
\text { UNESCO, a number of foreign foundations } \\
\text { ("Open Society" Institute, Inocenter, } \\
\text { Fulbright, IREX, DAAD, etc.). Over 40 } \\
\text { research grants have been received. } \\
\text { Since the beginning of the 21st century more } \\
\text { than } 60 \text { theses on the subject of media } \\
\text { education have been defended in Russia. }\end{array}$ \\
\hline 8 & $\begin{array}{l}\text { Positive and } \\
\text { negative } \\
\text { tendencies } \\
\text { of the } \\
\text { developmen } \\
\text { t of media } \\
\text { educational } \\
\text { process }\end{array}$ & $\begin{array}{l}\text { Despite the significant increase } \\
\text { of research work in the field of } \\
\text { media education its pace still lags } \\
\text { behind the needs of modern } \\
\text { society. } \\
\text { Media education is not } \\
\text { compulsory (except specialized } \\
\text { universities, schools and faculties } \\
\text { training professionals in the field of } \\
\text { media). } \\
\text { Media education in schools is } \\
\text { underdeveloped; it is integrated } \\
\text { into the basic subjects as well as } \\
\text { autonomous (optional, circle } \\
\text { studies). } \\
\text { Media education of teachers and } \\
\text { students of pedagogical universities } \\
\text { and is not implemented in practice } \\
\text { yet. } \\
\text { In general media education is } \\
\text { still far not only from wide practical } \\
\text { implementation but even from } \\
\text { noticeable experimental level. } \\
\text { Difficulties in the development } \\
\text { of media education nowadays are } \\
\text { connected with: } \\
\text { - the absence of specifically trained } \\
\text { media educators; }\end{array}$ & $\begin{array}{l}\text { An intensive research work is conducted } \\
\text { with the support of the Russian Ministry of } \\
\text { Education and Science, Russian } \\
\text { Humanitarian Scientific Foundation, } \\
\text { Russian Foundation for Fundamental } \\
\text { Research, Presidential Program "Support of } \\
\text { Russia's Leading Scientific Schools", } \\
\text { UNESCO, a number of foreign foundations. } \\
\text { Media education is not compulsory } \\
\text { (except specialized universities, schools and } \\
\text { faculties training professionals in the field of } \\
\text { media). } \\
\text { Media education in schools is } \\
\text { underdeveloped; it is integrated into the } \\
\text { basic subjects as well as autonomous } \\
\text { (optional, circle studies). } \\
\text { Media education of teachers and } \\
\text { students of pedagogical universities is not } \\
\text { compulsory and covers a limited number of } \\
\text { institutions. However in } 2002 \text { a university } \\
\text { specialization "Media Education" was } \\
\text { officially opened and gave prospects of } \\
\text { expanding the range of institutes of higher } \\
\text { education in Russia which introduce media } \\
\text { education into the educational process. } \\
\text { The role of pedagogical universities, } \\
\text { faculties of journalism and the media } \\
\text { community as a whole in the development of }\end{array}$ \\
\hline
\end{tabular}




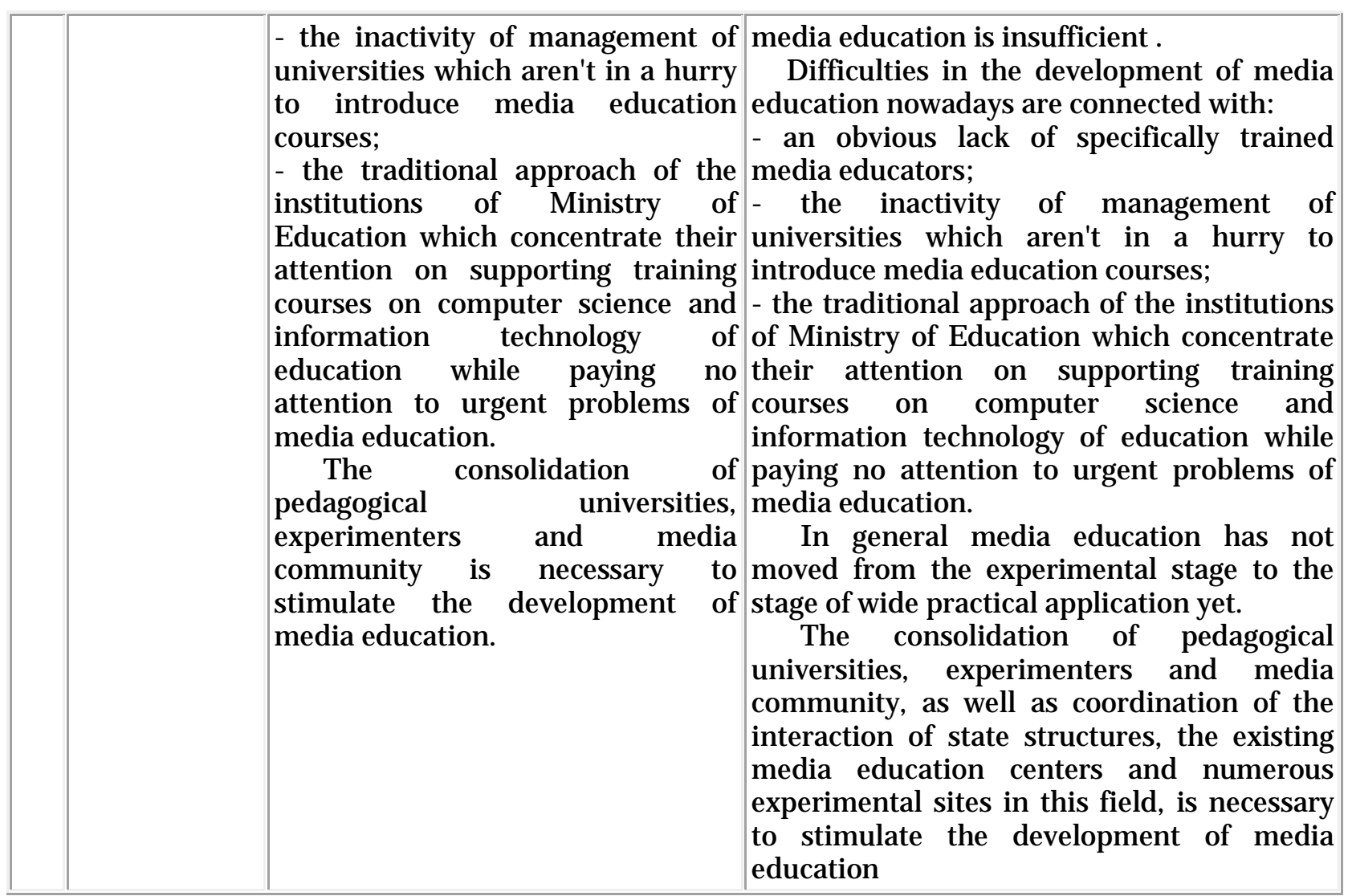

Table 1: Media education literacy in Russia and Ukraine:

comparative analysis of the present stage of development

CONCLUSIONS. As you can see from Table 1, despite similar problems and difficulties the development of media education in Ukraine lags behind the Russian level on a number of parameters. Today Ukrainian media educators share the urge to create a Ukrainian Association for Media Education (similar with the Russian one), to establish their own scientific journal (not only digital, but also printed version), in which they could publish articles on media education and media competence, to open a new university specialization "Media Education" with the qualification "media educator" (Onkovich, 2007(k), pp.358).

At the same time there are two competing trends in media education - Kiev and Lviv. Kiev group of media educators led by G.V. Onkovich gambles on media didactics - "a set of ordered knowledge, principles, skills, methods, means and forms of education process organization on the material of mass media with integration of media education into other disciplines" (Onkovich, 2007(l), p.358). While Lviv group of teachers focuses on the problems of media ecology and the connection of journalism with media education. Unfortunately these groups have not developed creative contacts with the Ukrainian Association for Film Education yet (the head of the Association - O. Musiyenko).

The situation changed in modern times: Russia is leading in media education literacy researches, but Ukraine is leading in the practical media education in schools.

Ukrainian media educators admit that media education in Ukraine still lags behind many countries (Naidyonova, 2007, p.163), however the increasing attention to the problems of media education (e.g. see theses of A.D. Onkovich, 2004 and I.M. Cheremis, 2008) in the two major Ukrainian research centers, Kiev and Lviv, allows to look optimistically into the future.

\section{REFERENCES:}

1. Barishpolets O. (2008). Media Education: Foreign Experience. Social psychology. №3 (29) http:www.politik.org.ua/ vid/ magcontent.php3?m $=6 \& n=84 \& \mathrm{c}=2072$

2. Bondur Y.V. (2005). Artistic Education of High School Pupils by Means of Media Culture. Scientific works. vol.42. N 29. pp. 111- 116. 
3. Buzhikov R.P. (2007). Innovation and Communication Technologies in System of Distance Learning. Higher Education of Ukraine. № 3. Appendix 3 (vol.7). Topical issue "Higher Education in Ukraine in the Context of Integration into European Educational Space: Education Quality Monitoring”. pp. 202- 206. $152 \mathrm{p}$.

4. Chashko L.V. (1979). Cinema, Radio and Television in Aesthetic Work. Kiev: Rad.shkola,

5. Chemeris I.M. (2006). Media Education Abroad: Theory of Media Education and a Brief History of Development. Higher Education in Ukraine. № 3.

6. Chemeris I.M. (2008). Formation of Professional Competence of J ournalists by Means of Foreign Periodicals. Abstract of thesis...candidate of pedagogical sciences. Kiev, $24 \mathrm{p}$.

7. Chernyavska Y.Y. (2005). Media Education in Great Britain and Canada. News for Education Process: Innovative Means and Technologies. Kiev, pp. 153- 175.

8. Chernyavska Y.Y. (2005). The Development of Media Education in Schools of Western Canada. Information Technologies and Training Aids / Editors V.Y. Bikov, Y.Y. Zhuk. Kiev, pp. 249- 255.

9. Chernyavska Y.Y. (2006). Media Education - Innovations in Canadian Schools. Ukrainian Principal. N3. pp.34-38. $708 \mathrm{p}$.

10. Fedorov A.V. (2001). Media Education: History, Theory and Methodology. Rostov.

11. Fedorov A.V. (2007). The Development of Media Competence and Critical Thinking of Students of Pedagogical Universities Moscow: Published by ICOS UNESCO "Information for All", $616 \mathrm{p}$.

12. Fedorov A.V. (2008). Media Education: Creative Tasks for Pupils. Open Lesson: development, technology, experience. № 1.

13. Fedorov A.V., Chelysheva I.V. (2002). Media Education in Russia: a Brief History of Development. Taganrog: Poznanie, 266 p.

14. Gabor N. (2002). Media Education or Instead of Epilogue. Media Attack / Compiled by B. Potyatinnik, editor N. Gabor. Lviv: Institute of Media Ecology, Media Center "NewJ ournalism", pp.49-52.

15. Goncharenko S.U. (1997). Ukrainian Pedagogical Dictionary. Kiev: Libid, 376 p.

16. Grishkova R.O., Onkovich G.V. (2006).The use of mass media in the formation of a foreign language social and cultural competence of students of non-philological specializations . Veresen. NN 3-4 (36- 37). pp. 35- 41.

17. Korochensky A.P. (2003). "The Fifth Power?” Media Criticism in Theory and Practice of J ournalism. Rostov: Rostov State University edition, 284 p.

18. Kozlova A. (2007). Foreign Experience in Training J ournalists. Higher Education of Ukraine. № 2. Appendix: topical issue "Pedagogy in High School: Methodology, Theory and Technology". vol.3. pp. 137- 139.

19. Kozlova A. (2007). J ournalism Education Abroad . Higher Education of Ukraine. № 2. pp. 105- 109.

20. Kozlova A. (2007). Journalism Education Abroad: Problems and Perspectives . Ukrainian Journalism: Conditions of Formation and Perspectives of Development / Editors: S.M. Kvit, T.G. Bondarenko. B. Khmelnitsky National University in Cherkasy, pp. 18- 20.

21. Kozlova G.V. (2007). J ournalism Education Abroad . Ugrent Theoretical and Practical Problems of Mass Media. S. Demyanchuk International Economical and Humanitarian University, pp. 21- 23. pp. 2-7.

22. Masol L. (2003). Media Culture as a Component of Education . Arts and Education. N2.

23. Media Attack (2002). Compiled by B. Potyatinnik. Editor N. Gabor. Lviv: Institute of Media Ecology, Media Center "NewJ ournalism", 56 p.

24. Media Education (1993). Russian Pedagogical Encyclopedia. vol.1 / Chief editor V.V. Davydov. Moscow: Bolshaya Rossiyskaya Encyclopedia, p. 555.

25. Media Education: Digital Journal of the Institute of Media Ecology / http:.www.franko.lviv.ua/ mediaeco/ zurnal/indexukr.htm

26. Naidyonova L.A. (2007). Perspectives of the Development of Media Education in the Context of the Bologna Process: Processual Model of Media Culture. The Bologna process and 
higher education in Ukraine and Europe: problems and perspectives. Kiev, pp.162-168. http:.www.edu.of.ru/mediaeducation/default.asp?ob_no $=30060$

27. Nedokhodyuk G.D. (2006). PR in the System of Higher Education . Higher Education in Ukraine. Appendix 3 (vol.2). Topical issue "Higher Education in Ukraine in the Context of Integration into the European Educational Process". pp. 282- 285.

28. Onkovich A.D. (2004). Formation of pedagogical competence of teachers of Ukrainian diaspora of the USA by means of pedagogical periodicals. Abstract of the thesis... candidate of pedagogical science. Kiev, $22 \mathrm{p}$.

29. Onkovich A.D., Onkovich G.V. (2007). Media Pedagogy and Media Education . Ukrainian Journalism: Conditions of Formation and Perspectives of Development / Editors: S.M.Kvit, T.G.Bondarenko. Khmelnitsky National University in Cherkasy. pp. 52- 57.

30. Onkovich G.V. (1997). Mass Media in Language Studies . Divoslovo, № 5-6. pp. 19-24.

31. Onkovich G.V. (2007b). Mass Media in Terminological Space of Media Education . Lexical and grammatical innovations in modern East Slavic languages / Compiled by T.S. Pristayko. Dnepropetrovsk: Thresholds, pp. 380- 383.

32. Onkovich G.V. (2007c). Media Didactics. J ournalism and Media Education-2007. 2nd edition, vol.1 / Editor Prof. A.P. Korochensky. Belgorod: Edition of Belgorod State University, pp.243-248.

33. Onkovich G.V. (2007d). Media Didactics in Teaching Russian as a Foreign Language . The world of Russian word and Russian word in the world. vol. 6 (2). Methods of teaching the Russian language (native, foreign). Sofia: Neron press, pp. 335- 340.

34. Onkovich G.V. (2007e). Media Pedagogy. Higher Education of Urkaine. № 2. Appendix 1. pp. 123- 125.

35. Onkovich G.V. (2007f). Media Pedagogy and Media Education: World Spread. Divoslovo. № 6. pp. 2-4.

36. Onkovich G.V. (2007g). Media Pedagogy. Media Education. Media Didactics. Urgent problems of humanitarian education / Editors G.V. Onkovich, A.M. Lomakovich, Kiev T. Shevchenko Regional Humanitarian and Pedagogical Institute, pp. 20- 25.

37. Onkovich G.V. (2007h). Media Pedagogy. Media Education. Media Didactics . Urgent theoretical and practical problems of mass media. S. Demyanchuk International Economical and Humanitarian University, pp. 16- 18.

38. Onkovich G.V. (2007i). Media Pedagogy. Media Education. Media Didactics . Higher Education of Ukraine. № 2. pp. 63-69.

39. Onkovich G.V. (2007j). Media Pedagogy as a Part of Media Culture . Collection of scientific works T. Shevchenko Regional Humanitarian and Pedagogical Institute in Kremenets. Issue 1. Series: Pedagogical Science. Kremenets: Regional Humanitarian and Pedagogical Institute, pp. 100- 107.

40. Onkovich G.V. (2007k). Technology of Media Education . Higher Education in Ukraine. № 3. Appendix 3 (vol.5). topical issue "Higher Education in Ukraine in the Context of Integration into European Educational Space: Education Quality Monitoring”. pp. 357- 363.

41. Onkovich G.V. (2007a). Mass Media in Terminological Space of Media Education. Divoslovo. № 5. pp. 29-31.

42. Piskun O.M. (2005). Media Education in Ukraine: Reality and Perspectives of Training of J ournalists . Scientists Notes. Simferopol. vol.18 (57). N3. pp. 97-99.

43. Potyatinnik B.V. (2002). Media Education: Journalism for All. http:.www.franko.lviv.ua/mediaeco/index.htm

44. Potyatinnik B.V. (2004). Media: Keys to Understanding. Lviv, Pais, 312 p. http:.www.franko.lviv.ua/ mediaeco/biblioteka/knyga.htm\#_Toc74750443

45. Potyatinnik B.V. (2005). Mass Journalism Education - why not? Media Criticism. № 10. pp.7-10.

46. Potyatinnik B.V., Lozinsky M. (1996). Pathogenic Text. Lviv: Missioner, 296 p.

47. Robak V. (2006). The Development of Media Education in Germany . Second Ukrainian Pedagogical Congress. Lviv: Kamula Ltd., pp. 275- 286.

48. Rumyantsev V.V. (2002). Media Education. Mirror of Europe. № 7. http:.hipressure.donbass.com/ edu/ conf2001/ rumyantsev.htm 
49. Sharikov A.V. (1990). Media Education: Russian and World's Experience Moscow: Academy of Pedagogical Science, $66 \mathrm{p}$.

50. Sharikov A.V. (1991). Media Education Concept in Secondary School. Moscow: Academy of Pedagogical Science, $23 \mathrm{p}$.

51. Shumaeva S. (2003). Media Education: Historical and Culturological Aspects of the Development. Ridna Shkola, N5. pp. 70- 72. $74 \mathrm{p}$.

52. Silina V.K. (1968). Cinema in School as Means of Aesthetic Education. Kiev: Rad.shkola,

53. Tyaglo O.V. (2002). Critical Thinking as a Part of Media Educationu . Media Attack / Compiled bu B. Potyatinnik. Editor N.Gabor. Lviv: Institute of Media Ecology, Media Center "New J ournalism", p. 35.

54. Yanishin O.K. (2007). Press Didactics and Press Linguodidactics Through the Prism of Media Education Scientific J ournal, M. Dragomanov National Pedagogical University. Series 7. Religious Studies. Culture. Philosophy. Issue 11 (24). Kiev: M. Dragomanov National Pedagogical University, pp. 226-228.

55. Yanishin O.K. (2007). The Role of Foreign Periodicals in Building Communicative Skills of Workers in Information Field (Media Didactical Approach). Higher Education of Ukraine. № 3. Appendix 3 (vol.5). Topical issue "Higher Education in Ukraine in the Context of Integration into European Educational Space: Education Quality Monitoring”. pp. 428-434.

\title{
УдК 372
}

\section{Россия и Украина: медиаобразовательные подходы}

\author{
Александр Викторович Федоров
}

Таганрогский государственный педагогический институт им. А.П.Чехова, Россия Ул. Инициативная, 48, Таганрог, Ростовская область, 347936

Доктор педагогических наук, профессор

E-mail: 1954alex@mail.ru

Аннотация. На протяжении многих десятилетий советского периода развития медиаобразования в России и Украине были практически совпадали. Медиаобразовательные занятия (в основном на материале кинематографа и прессы) были необязательны, имели очаговый характер и зависели от энтузиазма учителей. В теории и методике преобладали эстетические и практические подходы преобладают. В 1960-х - 1980х самых заявила о себе группа киевских кинопедагогов. Кроме кружков, факультативов (эстетический подход) и кино/фото/видеостудий, школьных и университетских газет и журналов (практический подход) медиаобразование развивалось в форме интеграции - в рамках обязательных предметов (таких как литература, история, русский, украинский, иностранные языки). Сегодня ситуация несколько изменилась: Россия опережает Украину в области медиаобразовательных исследований, а Украина Россию - в практическом внедрении медиаобразования в школах.

Ключевые слова: Россия; Украина; медиаобразование; медиаграмотность; школы; студенты. 